\title{
Changes in protein synthesis during maturation of sheep oocytes in vivo and in vitro
}

\author{
G. M. Warnes, R. M. Moor and M. H. Johnson* \\ Agricultural Research Council Unit of Reproductive Physiology and Biochemistry, \\ 307 Huntingdon Road, Cambridge \\ and \\ *Department of Anatomy, Downing Street, Cambridge, U.K.
}

\begin{abstract}
Summary. The qualitative profiles of the proteins synthesized by sheep oocytes at various stages of maturation were determined by electrophoretic separation in one dimension on polyacrylamide SDS gels.

No change in protein synthetic pattern was observed in oocytes removed before or up to $6 \mathrm{~h}$ after the release of LH in vivo. By $9 \mathrm{~h}$ intermediate changes had taken place in at least 12 separate protein bands. Marked alterations in the synthesis of some proteins were apparent $15 \mathrm{~h}$ after $\mathrm{LH}$; formation of proteins in 5 of the original bands was either reduced or not detectable, while new synthesis was evident from the appearance of 7 additional bands.

The pattern of proteins produced by oocytes cultured within the follicle corresponded closely with that observed in vivo: changes in synthesis were initiated about $9 \mathrm{~h}$ after addition of gonadotrophin and were completed by $15 \mathrm{~h}$. Oocytes cultured outside the follicle in a gonadotrophin-containing medium did not exhibit a change in protein synthesis and at $15 \mathrm{~h}$ only those proteins produced during the early stages of maturation were being synthesized.
\end{abstract}

\section{Introduction}

The nucleus of the mammalian oocyte enters prophase of the first meiotic division in the fetal gonad and thereafter remains in the dictyate stage until activated by the preovulatory release of gonadotrophin. The ensuing period of maturation is characterized by a series of clearly defined meiotic events in the nucleus. However, normal maturation also appears to be characterized by changes in the cytoplasm, because oocytes cultured outside the follicle satisfy the morphological criteria for nuclear maturation but fail to promote normal development of the male pronucleus following sperm penetration and have no capacity for further development (Thibault \& Gérard, 1973; Moor \& Trounson, 1977). We therefore believe that the gross morphological changes in the nucleus hitherto accepted as evidence of maturation are an inadequate index of the complete maturation of the oocyte and, in an attempt to define molecular correlates of normal cytoplasmic maturation, we have examined the profiles of proteins synthesized by sheep oocytes at various times after exposure to gonadotrophins in vivo and in vitro.

\section{Materials and Methods}

Protein synthesis by oocytes matured in vivo

Oocytes undergoing maturation in vivo were obtained from sheep in which the preovulatory release of LH was precisely timed by sequential treatment of each animal with PMSG, prostaglandin analogue (ICI 80,996) and LH-RH (Trounson, Willadsen \& Moor, 1976). In our sheep maximal LH release occurs within 2 h of the LH-RH injection (A. O. Trounson \& R. F. Simons, unpublished 
observation). Ovaries were removed at laparotomy immediately after the LH-RH injection $(0 \mathrm{~h})$ or at 3,6,9 and $15 \mathrm{~h}$ thereafter. Oocytes were obtained from non-atretic follicles of between 3 and 5 mm diameter (R. M. Moor, M. F. Hay, D. G. Cran and H. M. Dott, unpublished) and placed in basic medium (Dulbecco's phosphate-buffered saline containing $1.0 \mathrm{mg}$ glucose $/ \mathrm{ml}, 2.6 \mathrm{mg}$ lactate $/ \mathrm{ml}$ and $0.04 \mathrm{mg}$ pyruvate $/ \mathrm{ml})$ supplemented $1 \%(\mathrm{v} / \mathrm{v})$ with heterologous sheep serum. In preparation for incubation with radioactive amino acid, the oocytes were denuded of cumulus and corona cells by repeated pipetting before being transferred for 1-2 min to basic medium containing $0.1 \%$ protease (Sigma, London). Removal of the thinned and expanded zona pellucida was effected mechanically after thorough washing in basic medium containing $1 \%$ heterologous sheep serum.

Protein synthesis was determined by incubating, under sterile conditions, groups of 15-30 of the denuded, zona pellucida-free oocytes in $50 \mu$ protein-free basic medium containing $50 \mu \mathrm{Ci}$ L- $\left[{ }^{35} \mathrm{~S}\right]$ methionine (sp. act. 300-400 Ci/mmol: Radiochemical Centre, Amersham). After incubation for $3 \mathrm{~h}$ at $37^{\circ} \mathrm{C}$ in a humidified air atmosphere, groups of 5 oocytes (4-8 groups at each stage) were washed free of unbound label, placed in $20 \mu$ lysis buffer (Van Blerkom \& Brockway, 1975) and frozen at $-80^{\circ} \mathrm{C}$ until required for assay.

Labelled proteins were separated by electrophoresis at $15 \mathrm{~A}$ constant current for $5 \mathrm{~h}$ on polyacrylamide slab gels ( $7 \cdot 5-15 \%$ convex gradient) containing sodium dodecyl sulphate (Van Blerkom \& Brockway, 1975). After electrophoresis the gels were infiltrated with the scintillant PPO, dried under vacuum and exposed to RP 54 X-ray film for $1-5$ weeks at $-70^{\circ} \mathrm{C}$ (Laskey \& Mills, 1975).

\section{Protein synthesis by oocytes cultured in vitro}

Oocytes were cultured within the intact ovarian follicle (intrafollicular oocyte) or outside the follicle (extrafollicular oocyte). Non-atretic follicles (3-5 mm diameter) were dissected from the ovaries of untreated sheep between Days 4 and 14 of the cycle. Intrafollicular oocytes were cultured for 3,9 or $15 \mathrm{~h}$ in $5 \% \mathrm{CO}_{2}$ in air under hyperbaric conditions $\left(1.5 \times 10^{5} \mathrm{~Pa}\right)$ in Medium 199A supplemented with $2 \mu \mathrm{g}$ FSH (NIH-FSH-S8)/ml, $1 \mu \mathrm{g} \mathrm{LH}$ (NIH-LH-S18)/ml and $1 \mu \mathrm{g}$ oestradiol-17ß/ml (see Moor \& Trounson, 1977). Extrafollicular oocytes surrounded by their cumulus cells were removed from the follicle and cultured for $15 \mathrm{~h}$ in stoppered test tubes at atmospheric pressure in the same medium and gas phase used for the intrafollicular oocytes. The procedures for denudation of oocytes after culture, incubation and separation of labelled proteins were as described above.

\section{Results}

\section{Protein synthesis by oocytes matured in vivo}

Representative examples of gels showing the profile of proteins synthesized by groups of 5 oocytes at 3 and $15 \mathrm{~h}$ after the injection of LH-RH are shown in Plate 1. Text-figures 1(a)-(e) show the changes in synthesis of 12 selected protein bands by groups of oocytes examined at intervals during maturation in vivo. Oocytes taken from follicles at 0,3 or $6 \mathrm{~h}$ after injection of LH-RH yielded similar protein profiles (Text-figs 1a-c). There was a pronounced change in protein synthesis between 6 and $15 \mathrm{~h}$ after LH-RH administration (Text-figs $1 \mathrm{c}$ and 1e). Many protein bands changed qualitatively and quantitatively over this period, but the 12 that could be most clearly resolved are indicated in Plate 1 . Seven of the protein bands showed a marked increase (A, B, D, E, G, I, K) and the other 5 bands disappeared or became very weak (C, F, H, J, L). Oocytes removed at $9 \mathrm{~h}$ showed an intermediate pattern in which some of the protein bands characteristic of early maturation were still present in a proportion of oocytes and not all of the bands associated with later maturation had yet appeared (Text-fig. 1d).

\section{Protein synthesis by oocytes cultured in vitro}

The profiles of proteins synthesized by oocytes cultured within the intact follicle in vitro corresponded closely with those observed when oocytes were matured in vivo. The protein bands $\mathrm{C}, \mathrm{F}, \mathrm{H}$, 
PLATE 1

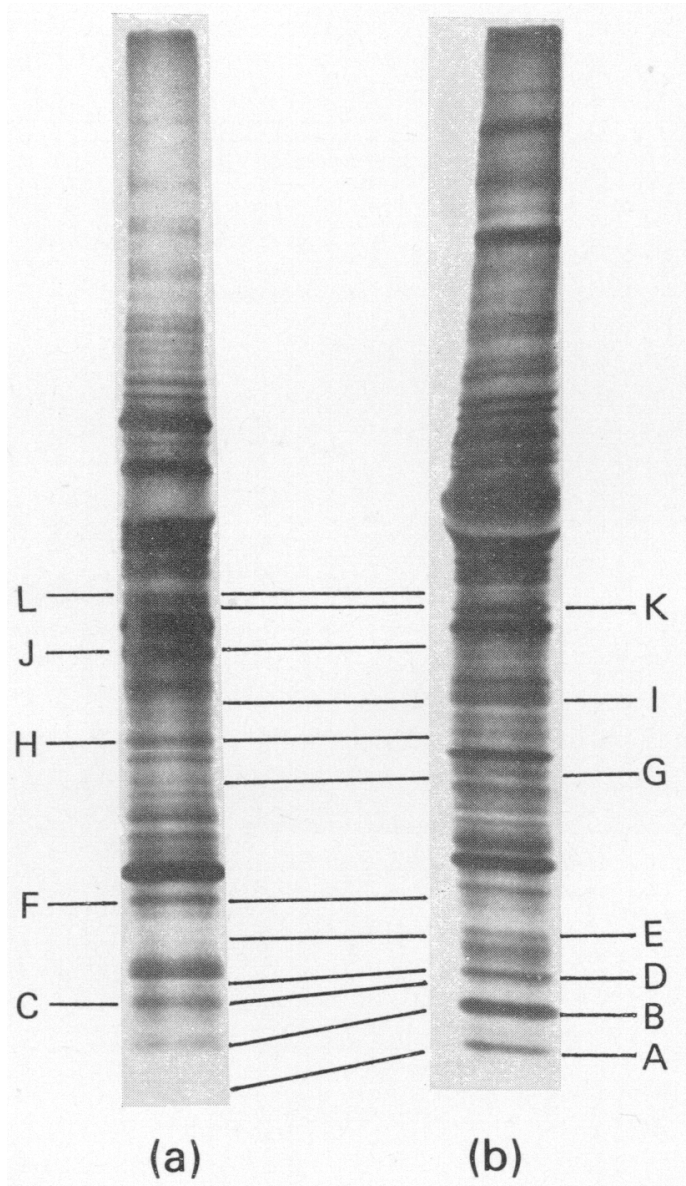

Electrophoretic separation of proteins synthesized by sheep oocytes matured in vivo for (a) $3 \mathrm{~h}$ and (b) $15 \mathrm{~h}$ after injection of $\mathbf{L H}-\mathrm{RH}$. Letters indicate protein bands changing during this period. Bands $\mathrm{C}, \mathrm{F}, \mathrm{H}, \mathrm{J}$ and $\mathrm{L}$ are strong early in maturation, and bands $\mathrm{A}, \mathrm{B}, \mathrm{D}, \mathrm{E}, \mathrm{G}, \mathrm{I}$ and $\mathrm{K}$ are strong late in maturation. 
(a)

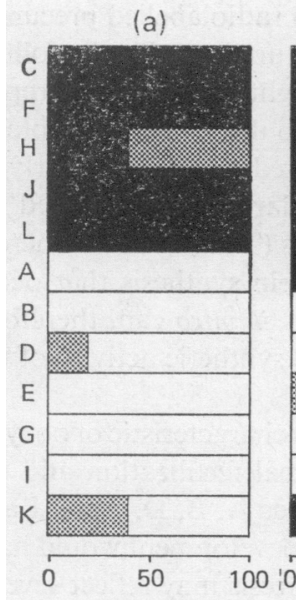

(f)

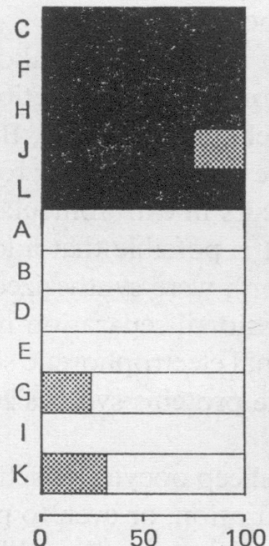

(b)

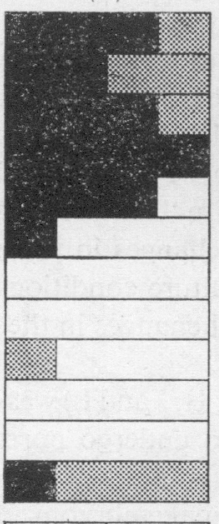

$50 \quad 100$

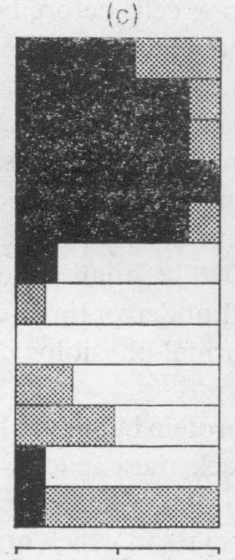

50

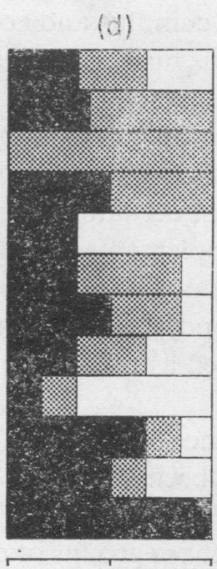

50

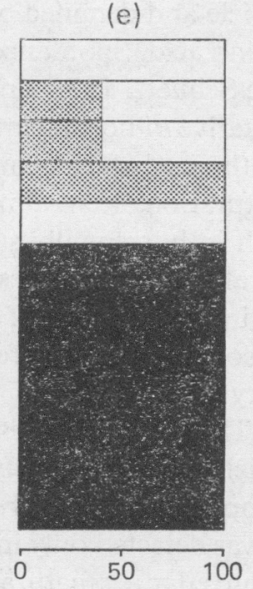

(i) (g)

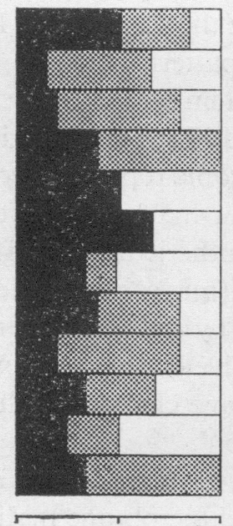

(h)

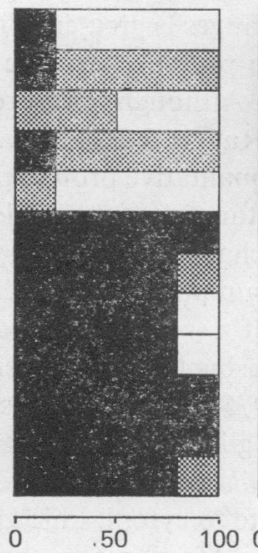

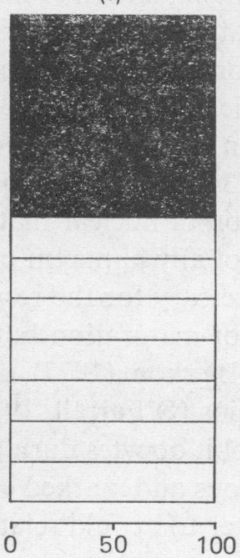

Text-fig. 1. Changes in the pattern of synthesis of 12 electrophoretically separated protein bands (A to L; see Plate 1) in sheep oocytes at various times after exposure to gonadotrophins in vivo or in vitro. The diagrams show the percentage of oocytes in which the protein bands $A$ to $L$ are strongly present (black), weakly present (stippled) or absent (white). a-e, oocytes matured in vivo for $0,3,6,9$ and $15 \mathrm{~h}$ respectively, after LH-RH injection; $\mathbf{f}-\mathbf{h}$, intrafollicular oocytes cultured in vitro (see text) for 3,9 or $15 \mathrm{~h}$; $\mathbf{i}$, extrafollicular oocytes cultured in vitro (see text) for $15 \mathrm{~h}$.

$\mathbf{J}$ and $\mathbf{L}$ (early proteins) were present in almost all the oocytes cultured for $3 \mathrm{~h}$; bands A, B, D, E, G, $\mathrm{I}$ and $\mathrm{K}$ (late proteins) were, by contrast, largely absent at this stage (Text-fig. 1f). After $9 \mathrm{~h}$ culture an intermediate pattern of proteins was observed (Text-fig. 1a), whilst at $15 \mathrm{~h}$ there was active synthesis of 'late' proteins and little synthesis of the proteins characteristic of early maturation stages in vivo (Text-fig. 1h). Removal of the oocyte from the follicle before culture affected profoundly its subsequent synthetic capacity (Text-fig. 1i). Even after $15 \mathrm{~h}$ in culture in the presence of LH extrafollicular oocytes were still synthesizing only those proteins associated, in intrafollicular oocytes, with early maturation.

\section{Discussion}

This study demonstrates that marked qualitative changes occur in protein synthesis during maturation of oocytes both in vivo and in vitro under conditions compatible with subsequent normal fertilization and embryonic development (Moor \& Trounson, 1977). Caution is necessary in the interpretation of some of our findings, since the technique necessitates that oocytes must be removed from the 
follicle and denuded of cumulus and corona cells before being incubated in radiolabelled precursor amino acid. Spontaneous nuclear activation occurs regularly in oocytes matured outside the follicle (see Schuetz, 1974) and protein synthesis by denuded oocytes in culture might likewise be unrepresentative of normal intrafollicular synthetic activity. However, the changes in the profiles of proteins synthesized during maturation, as distinct from the basal pattern observed before and early in maturation, seem almost certain not to be artefactual because extrafollicular oocytes cultured for $15 \mathrm{~h}$ in hormonally supplemented medium do not synthesize 'late' proteins (Text-fig. 1(i)) whereas intrafollicular oocytes do (Text-fig. 1(h)). The qualitative changes in protein synthesis that occur during maturation of oocytes in vivo and under optimal culture conditions in vitro can, therefore, reasonably be interpreted as reflecting normal physiological changes in the synthetic activity of the oocyte.

The continued presence of five 'early' protein bands (C, F, H, J and L) was characteristic of oocytes which have previously been shown to lack the capacity to undergo normal fertilization and development (see Moor \& Trounson, 1977). In contrast, the synthesis of Bands A, B, D, E, G, I and $\mathrm{K}$ was detected only in those groups of oocytes in which normal embryonic development would have occurred after maturation. Since each band on one-dimensional electrophoresis may reflect several species of protein, and since not all bands have been analysed in detail, the number of proteins showing functionally dependent changes is greater than the 12 reported here.

The major changes in the protein synthetic pattern occur just before the breakdown of the germinal vesicle (Dziuk, 1965). Although some protein synthesis is required for completion of meiotic maturation in the rat (Stern, Rayyis \& Kennedy, 1972; Tsafriri, Lieberman, Barnea, Bauminger \& Lindner, 1973), the switch in qualitative protein profile reported here does not appear to be essential for completion of nuclear maturation since nuclear maturation occurs in extrafollicular oocytes in the absence of any apparent change in protein synthetic activity. It is possible that additional new proteins, necessary for the resumption of meiosis (nuclear activation), were synthesized during the early stages of maturation but were not resolved by the one-dimensional separation methods employed. Van Blerkom (1977), using the more sensitive two-dimensional electrophoretic separation of oocyte proteins (O'Farrell, 1975), has reported some changes in the proteins synthesized by extrafollicular rabbit oocytes during in-vitro 'maturation'.

The obvious and marked change in the proteins synthesized by sheep oocytes which occurred at about $9 \mathrm{~h}$ after $\mathrm{LH}$ could relate to cytoplasmic and membrane maturation, or even to post-maturational events essential for normal fertilization and development. Evidence to support this conclusion comes from the observations that (i) nuclear activation can be dissociated from the attainment of subsequent developmental capacity in sheep oocytes (Moor \& Trounson, 1977), and (ii) the pronuclear activating protein which appears in the ooplasm after germinal vesicle breakdown is not present in the ooplasm of rabbit oocytes matured outside the follicle (Thibault, Gérard \& Menezo, 1975). The failure of oocytes cultured outside the follicle to undergo similar changes in protein synthesis to those observed in oocytes both in vivo and during intrafollicular culture in hormonally supplemented media may be due to inadequate culture conditions or lack of a specific signal from follicular cells.

It is not clear from published data whether control of protein synthesis in the maturing oocyte is exerted at the transcriptional or the translational level. The chromosomes of the mammalian oocyte, like those of amphibians (La Marca, Smith \& Strobel, 1973), are actively synthesizing RNA from early in follicular growth to within an hour or so of germinal vesicle breakdown and some of the RNA is released into the ooplasm before germinal vesicle breakdown (Bloom \& Mukherjee, 1972; Rodman \& Bachvarova, 1976; Wasserman \& Letourneau, 1976). Concomitant with germinal vesicle breakdown, presynthesized RNA passes into the ooplasm and species of RNA coding for new proteins synthesized after germinal vesicle breakdown could become available (Rodman \& Bachvarova, 1976). However, much of the recently synthesized RNA is carried over into the fertilized egg (Rodman $\&$ Bachvarova, 1976), where it may have a role in early development. The experiments reported here suggest that the carry-over or activity of recently synthesized protein may also be important for the success of post-maturation development, in addition to having a role in the final phases of maturation itself. 
We thank Professor T. Mann and Dr Mary Hay for helpful criticisms, and Debbie Eager and Mitzi Gooding for technical assistance. This work was supported by grants from the M.R.C. to M.H.J. and to Professor C. R. Austin from the Ford Foundation. Purified gonadotrophins were kindly supplied by NIAMDD.

\section{References}

BloOM, A.M. \& MUKherjee, B.B. (1972) RNA synthesis in maturing mouse eggs. Expl Cell Res. 74, $577-582$.

DzIUK, J.P. (1965) Timing of maturation and fertilization of the sheep egg. Anat. Rec. 153, 211224.

LA MarCa, M.J., SMTTH, L.D. \& STrobel, M.C. (1973) Quantitative analysis of RNA synthesis in stage 4 and stage 6 oocytes of Xenopus laevis. Devl Biol. 34, 106-118.

LASKeY, R.A. \& MILls, A.D. (1975) Quantitative film detection of ${ }^{3} \mathrm{H}$ and ${ }^{14} \mathrm{C}$ in polyacrylamide gels by fluorography. Eur. J. Biochem. 56, 335-341.

Moor, R.M. \& Trounson, A.O. (1977) Hormonal and follicular factors affecting maturation of sheep oocytes in vitro and their subsequent developmental capacity. J. Reprod. Fert. 49, 101-109.

O'Farrell, P.H. (1975) High resolution two-dimensional electrophoresis of proteins. J. biol. Chem. 250, 4007-4020.

Rodman, T.C. \& BachVarova, R. (1976) RNA synthesis in preovulatory mouse oocytes. J. Cell Biol. 70, 251-257.

SchuETz, A.W. (1974) Role of hormones in oocyte maturation. Biol. Reprod. 10, 150-178.

Stern, S., RayYIS, A. \& KenNedy, J.F. (1972) Incorporation of amino acids during maturation in vitro by the mouse oocyte: effect of puromycin on protein synthesis. Biol. Reprod. 7, 341-346.
Thibault, C. \& Gérard, M. (1973) Cytoplasmic and nuclear maturation of rabbit oocytes in vitro. Annls Biol. anim. Biochim. Biophys., Suppl. 13, 145-156.

Thibault, C., Gérard, M. \& Menezo, Y. (1975) Acquisition par l'ovocyte de lapine et de veau du facteur de décondensation du noyau du spermatozoide fécondant (MPGF). Annls Biol. anim. Biochim. Biophys. 15, 705-715.

Trounson, A.O., Willadsen, S.M. \& Moor, R.M. (1976) Effect of a prostaglandin analogue, cloprosterol, on oestrus, ovulation and embryonic viability in sheep. J. agric. Sci., Camb. 86, 609-611.

TSAFrIRI, A., LIEBERMAN, M.E., BARNEA, A., BAUMINGER, S. \& LINDNER, H.R. (1973) Induction by luteinizing hormone of ovum maturation and of steroidogenesis in isolated Graafian follicles of the rat: role of RNA and protein synthesis. Endocrinology 93, 1378-1386.

VAN BLERKoM, J. (1977) Molecular approaches to the study of oocyte maturation and embryonic development. In Immunobiology of Gametes, pp. 187-206. Eds M. Edidin \& M. H. Johnson. Cambridge University Press.

VAN BLERKOM, J. \& BROCKWAY, G.O. (1975) Qualitative patterns of protein synthesis in the preimplantation mouse embryo. I. Normal pregnancy. Devl Biol. 44, 148-157.

WASSERman, P.M. \& Letourneau, G.E. (1976) RNA synthesis in fully-grown mouse oocytes. Nature, New Biol. 261, 73-74. 